\title{
Measuring the Quality of God's Servants According to Acts 6: 3 At the Surabaya City Tabernacle Pentecostal Church Widi Prasetyo ${ }^{1)}$ Juanda ${ }^{2)}$ Surja Permana ${ }^{3)}$ Daniel Ari Wibowo ${ }^{4)}$
}

\author{
1) Evangelical Theological Seminary of Indonesia - Surabaya \\ E-mail:widiprasetyo@sttii-surabaya.ac.id \\ 2) Evangelical Theological Seminary of Indonesia - Surabaya \\ E-mail: juanda@sttii-surabaya.ac.id \\ 3) Evangelical Theological Seminary of Indonesia - Surabaya \\ E-mail:surjapermana@sttii-surabaya.ac.id \\ 4) Evangelical Theological Seminary of Indonesia - Surabaya \\ E-mail:ariwibowodaniel@sttii-surabaya.ac.id
}

\begin{abstract}
Research on the Implementation of the Qualifications of God's Servants According to Acts 6: 3 In the Pentecostal Church of Surabaya City Secretariat, wanted to find out the whereabouts of God's servants in the study according to Acts 6: 3, especially in the scope of the Pentecostal Church Surabaya City Tabernacle. Specifically chapter 6: 3, explains the essence of the solution to the problem, namely the selection of 7 servants of God. Obviously Dr. Luke reveals the criteria of God's servant who can be the solution to the problems that occur. At present, most Churches of God are more concerned with the physical buildings, facilities and infrastructure of the Church rather than thinking about how to get God's servants who can answer the needs of the congregation and the challenges of the times. What is even more concerning is that many of the Churches of God are procuring servants of God who only look at the side that can increase the image and popularity of the Church. So often the Church is
\end{abstract}

Keywords: Qualifications, Servants of God, Divine Mandate,Standardization.

\section{INTRODUCTION}

Humanwith all of its existence and creativity will continue to bring up a civilization that is always changing all the time. Primitive times, farming and industry have long passed. Today's world is no longer modern but super modern. Super sophisticated telecommunications facilities have made the world feel cramped. With world phenomena like this, of course, bring changes to people's

attitudes, needs and behavior. The demands and challenges of humans are not light but are increasingly complex.

The development of increasingly advanced technology will of course bring positive or negative impacts. The positive side is the processing of the earth and its contents for the good of humans. This is in accordance with the biblical teachings that evangelicals hold are called the Divine mandate of development. This task was given by God in the garden of Eden before the fall (Gen. 1: 28$30 ; 2: 15)$.
Humans as perpetrators and users of the results of modernization that has been dominated by $\sin$, the negative impact of modernization is inevitable. To overcome this need sensitivity and alertness to the effects of these impacts.

Regarding the kinds of negative impacts arising from modernization, Chris Marantika stated that at least five negative impacts have arisen.[1] Namely:

The first negative impact is liberalism. This understanding emphasizes absolute habits (Liberty) in all areas of life. So the gospel of salvation in the Lord Jesus Christ is considered ancient, irrelevant and obsolete.

The second negative impact is understanding individualism. This understanding emphasizes individual benefits above mutual interests and benefits. Unhealthy competition and even cheating are practiced without considering the negative impact on others. Exploitation, manipulation, 
etc.are actions that are considered reasonable, in the interests of their own affordable. These things are justified on the pretext that humans are absolutely free creatures.

The third negative impact is materialism. The business goal is directed at providing maximum material benefits in various ways to obtain them. All success criteria are measured in terms of material success.

The fourth negative impact is the overreliance on human ability. Advances in science and technology tempt humans to depend on humans and the modern tools they have. Reason, prayer, and miracles are excluded as unimportant things.

The fifth negative impact is the existence of human exploitation of humans. The habit of dealing with machine tools makes people lose respect for each other. Instead of using things and loving humans, modern humans are more like each other and love things. Human value is exchanged for the value of goods or money.

Chris Marantika's statement is a real thing in this era. Everyone can see and feel it. This reality matches what the Word of God revealed in 2 Timothy $3: 1-5$, which says:

"Know that in the last days difficult times will come. Human will love himself and become slave for money. They will brag and boast, they will become vilification, they will rebel against parents and do not know thank you, do not care about religion, do not love, do not want to make peace, do not make people bad, can not curb themselves, fierce, do not like the good, likes to betray, do not think long, pretend to know, obey the passions rather than obey God. Outwardly they perform worship they are, but in essence they deny their power. Stay away from them. "[2]

The negative effects of the results of modernization are not enough to know but a solution needs to be found. This requires the role of the church to pay attention to fundamental horizontal issues such as justice, control and respect for life as God's grace and attention to those who are weak and powerless. Therefore it is necessary for the Church to concretize it and intensify Church programs that are horizontal and aimed out for the interests of the community.[3] To answer and provide solutions to problems that are happening due to the negative impact of modernization, the authors pour in the paper.

Literally ecclesiology means

understanding of the church. Every Christian must have a diverse understanding. Many Christians still understand the church as a place (a building of worship with all its equipment). Some understand the church as an institution or social organization. There is also a view that the Church prefers spiritual or inner aspects. In the case of the Church is defined as fellowship or community of people who believe in Christ, without too much care for the institutional and organizational order.[4] The church is often also interpreted to mean all Christians, regardless of prejudice, denomination, ethnicity, nationality or social status. Regarding the meaning of the Church is a believer, it means that the Church is not an organization but an organism.[5] As organisms the Church must experience growth. The problem of the growth of the Church today is being discussed and is being studied everywhere, in various denominations throughout the world. Church growth does not only focus on the large number of church members, the large amount of mission funds, the number of missionaries, or the large amount of mission funds, but also focuses on spiritual growth, so that people who are out of salvation truly repent and return truly repent and return to God; so that all nations become disciples of God; so that the church develops and grows into adulthood, can preach the gospel can build more churches.

Church growth is not a new mode or modern item, but a task that is very urgent and cannot be delayed. Judging from the existence of various pressures from this world, then if we do not quickly grow, we will lose a place to stand, the existence of the Church will get into trouble. Church growth is not only the existence of Christianity, it also determines the triumph or decline of Christianity. The church is fast growing, the existence of Christianity is getting stronger; The church is not growing, Christianity is certainly backward.

Church growth is influenced by several factors. With regard to the topic of factors that support the growth of the Church, Chris Marantika argues that: When examined closely, both from a biblical and historical standpoint,is itclear that the main factors causing a surge of rapid growth are factors: (1) Central Dynamics: (2) Servants of God: (3) Containers for implementation (Divine institutions); (4) Gospel News. If the four growths will be dynamic and bear fruit it will 
no doubt be dynamic and healthy fruitful.[6] So according to Chris Marantika one of the main factors causing the growth of the Church is the servant of God / servant of God himself. The Triune God does not work through a vacuum. He works through the means and servants of God who are right and of high quality. God's servant in general terms is called human resources.

Human resources, which is then abbreviated as HR, is the potential contained in human beings to realize their role as human beings who are human and transformative who are able to manage themselves and all the potential contained in nature towards the achievement of the welfare of life in a balanced and sustainable order. In everyday practical sense, HR is better understood as an integral part of the system formed by an organization. Human resources consist of employees who work based on their expertise and work in a field or department in accordance with their respective expertise.[7] In terms of the function or importance of human resources Marihot Tua Effendi Hariandja argues that human resources (HR) is one very important factor in a company in addition to other factors such as capital. Therefore, HR must be managed well to increase the effectiveness and efficiency of the organization, as one of the functions in the company known as human resource management (HRM).[8] The above statement explains the definition and function of human resources in general.

In the world of service, God's servant or servant of God is also the most valuable asset in a ministry. Capital in the form of material and infrastructure will not be meaningful without the servants of God. Paul G. Caram argues that:

"Statistics say that the average servant of God affects about 10,000 people while serving. This investigation includes the servants of God who serve in small cities as well, not only in big cities. Through relationships that he established when he served the blessing of marriage or funeral, through articles he wrote in the newspapers, through interviews on the radio, through speeches at graduations, prayers at dedication programs (children, homes, etc. others), hospital visits, or sermon tapes sent to relatives or friends, generally a servant of God reaches thousands of people. Power of Attorney and According to the author, the opinion of Paul G. Caram who highlights the influence of God's servants is logical. This will be proven if the person being investigated is an active servant of God and exists in many fields of service. From the content of his opinion, it is clear that the service of God or God's servants is something vital, which greatly influences the success or failure of a ministry.

Regarding the importance of human resources, Sonny Eli Zaluchu stated that:

"The Church often places success through improving supporting facilities and infrastructure. The more stately buildings, the quantity of congregations continues to grow, more and more offering money is a significant empirical measure of success. This fact makes us forget that the quality aspects of human resources are neglected and not prioritized. We forget that humans are the most valuable asset in an organization as large as the Church. Church leaders in addition to running programs or doing hardware improvements, also have to send workers to seminars, trainings, read books, to empower their abilities at an effective level. "[10]

The author strongly agrees with Sonny Eli Zaluchu's expression. Because indeed what is often done by the Church only prioritizes revamping and procuring facilities and becoming a brand image of the success of the Church. It should be underlined, that the future of the Church, even the future of the nation will be largely determined by the availability of qualified human resources.

To be able to produce qualified human resources / servants of God, it is necessary to set a certain qualification standard in accordance with the truth of God's Word. In this connection, George W. Peters said some of the main characteristics of a servant of God whose life can be used by God to bring forth the growth of His Church.[11] First, He has accepted the call of the Lord Jesus Christ and remains faithful to follow God in any situation, despite his weaknesses and limitations, he will faithfully say, just like Peter "Lord, to whom shall we go?" (John 6:68) Second, he is a servant who voluntarily enters service to Christ and his Church, without ambition seeking material wealth and personal interests (Matt. 26: 57-62; 14: 2533). 
Third, he is a servant of God who experiences a deeper and deeper fellowship with God, so that he is not only able to convey His Word, but also able to explain the principles he teaches and radiate God from himself (I Pet. 2: 9). Fourth, He is a servant of God who lives in the Spirit (Gal. 5:25; Eph. Fifth, He is a servant of God who has set his priorities in life both in personal life and ministry (Matt. 6:33).

Sixth, He is the servant who receives and applies the ministry together as a team (Acts 3: $1,4 ; 4: 23-31)$.

Seventh, He is a servant who has the message of the Gospel of Salvation burning in his heart. God's pressure surged in the bosom of God's servant causing him to be unbearable in the proclamation of the Gospel of Salvation (Acts.4: 19-20).

Eighth, $\mathrm{He}$ is a servant who is willing to sacrifice and is willing to suffer even death even for the preaching of the gospel in the Lord Jesus Christ who died even for the preaching of the gospel in the Lord Jesus Christ who died and rose to this world (Acts 4: 12-31; $7: 60$ ). This was done joyfully (Phil. 4: 4-9).

Ninth, $\mathrm{He}$ is a servant whose message comes from God's Word (I Tim. 4: 2a), not from dogeng or his experience. George W. Peter's statement above is a basic criterion that must be possessed by a servant / servant of God in addition to the other criteria. Determination of the criteria is intended to get qualified servants of God and in accordance with the needs of the existing field of service

\section{The Meaning of Waiters}

Judging from the meaning of the word servant means people who serve, helpers, messengers. Deacon (Latin: Diaconus) is a role in the Christian Church that is generally associated with service in several different fields, according to theological and denominational traditions.

The word deacon is derived from a Greek word diakonia (service), diakonein (airport), and diakonos (waiter). In many traditions, the diaconate (office of deacon) is aoffice; clericalin other traditions, deacons are for lay people.

The word deacon comes from the Greek

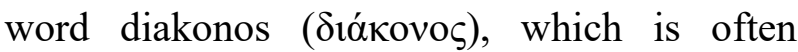
translated as a waiter or more specifically a waiter in the table (English: waiter). In the Greek world, these deacons are seen as slave labor and low labor.

The Greek word dikononos can be used to mean: messenger, servant, house servant, deputy captain, attendant at religious ceremonies, and especially service at banquets. Its use in the NT also has several meanings: (a) In the general sense it is used to refer to the servant of a superior (Matt. 22:13) or the servant of one another (Mk 9:35; 10:43; Matt. 20:26). (b) In a more limited sense it is used to refer to every Christian as a servant of Christ (John 12:26; 2 Cor 11:23) or servant of God (2 Cor 6: 3 and so on). (c) In a figurative sense it is used for human understanding which could be a devil servant or a servant of justice (2 Cor 11: 14-15), servant of the gospel (Eph. 3: 6-7; Col. 1:23), servant of sin (Gal. Gal. 2:17), servants who are circumcised (Rom. 15: 8) or NT servants (2 Cor 3: 6).

Therefore, selection in the recruitment of servants of God based on criteria that are in accordance with God's Word is not something incidental in certain periods. But it should be sustainable and will remain relevant today. This is because the Church will continue to need qualified servants of God. Servants of God who are

able to overcome and provide solutions to the Church's internal and ecological problems so that the Church will experience growth.

Once the importance of the role of servants in the progress and success of a ministry, then it takes a selection in the provision of servants of God in a church or place of service. Lately looking for servants of God is getting harder and harder. The fewer people can be chosen and the more people who refuse to serve. And even if there were, certainly not a servant of God who lives to serve but to serve for life. In other words, someone who wants to be a servant hopes to earn a living from the place or church where he serves. So many offer themselves as servants of God with various demands for facilities, materials and infrastructure. Suharto Harjowinoto and Heru Susanto said that for a servant of God, it should not demand the church's tithe / contribution for his life but rather focus on the task of churching together with members of the congregation, while the congregation wisely looks at the needs of his family and his ministry life.[12] 
This statement means that the part that must be done by the Lord's servant is to focus on his ministry. A sovereign God who will guarantee the lives of His servants. He was also able to move the church that His servants served as a channel of blessing for him. The mistake often made when choosing God's servant is to rely on one's own strength and wisdom and not to seek God's will. Very dangerous if in the end the people chosen to serve God are people who have no heart, or rather those who are not God chose.

The phenomenon that occurs in the field of service, the error that is in the selection of God's Servant is an element of intent. This occurs because of certain interests of the person or organization of the Church. For example, churches which prioritize intellectuals will tend to choose highly intellectual servants without regard to their character or spirituality. Churches that prioritize character will choose God's servants who are of good character even though they are less spiritual and broad-minded. Likewise, churches which prioritize spirituality will choose ministers who have good vertical relations even though horizontal relationships and theological understanding are not good.

There are even churches that need funding to grow and tend to choose God's servants who have a lot of money without regard to intellectual, spiritual and character qualities.

The selection of servants of God that only refers to one side, will make the problems faced in the ministry not resolved properly. The selection of services whose main purpose is to minimize problems and even solve problems and make services more advanced, on the contrary the problem becomes more complex and the service is destroyed.

\section{Problem Identification}

Selecting a problem is the first step of a research activity. Problems are part of a person's need to be solved. People wantMen to conduct research because he wants the problems he faces get answers. The problem search / selection activity begins with the selection of research topics. Armed with the topic, the work is long enough, namely to examine the sources of the problem with a view to finding and establishing problems related to the topic. This step in research is called problem identification.[13]

From the study of the problems found in the background of the problem, researchers can identify several problems: First, cultural and technological changes in addition to having a positive impact but also a negative impact on humans. Second, the church is needed to pay attention to the fundamental horizontal problems. Third, the church must grow if it wants to play a role. Fourth, one of the main factors in church growth is theHuman Resources / Servants of God Fifth. There needs to be a standardization of God's servant qualifications in order to produce servants who answer the challenges of the Age of

\section{Limitations}

In this study, researchers limit it by giving the research title: Acts 6: 3 in the Tabernacle Pentecostal Church in Surabaya. So what was discussed and examined only about the qualifications of the Lord's Servants was found in Acts 6: 3 and only about the place of research in the Pentecostal Pentecostal Church in Surabaya.

\section{Problem Formulation The}

formulation of the problem in this study, are: First, Does the Servant of God Pentecostal Church Tabernacle carry out qualifications Acts 6: 3 Two, How big is the Servant of God Tabernacle Pentecostal Church in the whole city of Surabaya carrying out qualifications of Servants of God according to Acts 6: 3

\section{Research Objectives}

The purpose of this study are: First, Can show whether the Servant of the Pentecostal Pentecostal Church carry out qualifications Acts 6: 3

Second, Can show how much the Servant of the Pentecostal Pentecostal Church throughout the city of Surabaya carry out the qualifications of the Servant of God according to Acts $6: 3$ 


\section{Benefits of Research}

And the benefits of this study are: First, For Researchers, For the church under study. For researchers, providing learning and training to obtain qualification standards for ministers of God and measure how much of this qualification is in the service of the Lord of the Tabernacle Pentecostal Church in the city of Surabaya. For the church that is examined, can find out how much the qualifications of Ministers in Acts 6: 3, and can be a reference material and consideration in fostering and developing the character and skills of ministers.

Second, this research can add insight and knowledge about how to qualify God's servants according to the truth of God's Word.

Third, this research becomes a preliminary research / initial analysis which is very useful for the development of further research both quantitative and qualitative research.

\section{Conclusion}

From the presentation of the theory about the meaning of deacons / servants of God, the task of deacons, it can be understood that the servants of God have a very large contribution to the growth and development of the Church. So it takes the right way in the procurement and provision of God's servants. But it is unfortunate that this has not been fully realized and addressed by God's Churches until now. Most Churches of God pay more attention to the physical buildings, facilities and infrastructure of the Church rather than thinking about how to get God's servants who can answer the needs of the congregation and the challenges of the times.

Even more alarming is the many Churches of God who procure servants of God who only look at the side that can increase the image and popularity of the Church. So often the Church is more concerned with intellectuals and skills without regard to character. This has become a gap problem in the Church and even divisions within the Church. Because of the reality that happens a lot in the field is what makes the writer moved to discuss and at the same time provide a solution. In order to finally emerge an awareness of the importance of the Servant of God and the movement for change that is leading to an increase both in the provision and provision of God's servants. Book of Acts is the second book written by Dr. Luke The contents of the book of Acts are about the coming and activities of the Holy Spirit as well as about the activities of the early Church. In chapters 6: 1-6, describes one of the problems that occur. One problem that can cause disintegration or division among the early church. But because of the excitement of the work of the Holy Spirit and the submission of the apostles to the leadership of the Holy Spirit finally obtained a very appropriate solution, which not only solved the existing problems but brought about an impact of growth both in quality and quantity. Specifically chapter 6: 3 , explains the essence of the solution to the problem, namely the selection of 7 servants of God. Obviously Dr. Luke reveals the criteria of God's servant who can be the solution to the problems that occur.

His qualifications are well-known / well-known. This means that other people judge, witness and report the good things of the servant's personality, namely: First, have honesty. In this case, a servant of God is an honest person. Honest means not lying, not taking other people's property, not cheating, telling the way it is. Second, sincerity, clean heart and sincere / willing heart. Third, a servant of God must have integrity. Integrity is responsible and committed to commitment.

Fourth, filled with spirit means life that is led, controlled, controlled and controlled by the Holy Spirit.

The fullness of the Spirit will be expressed through the attitude of life in accordance with the fruits of the Spirit and the characteristics of people who live according to the Spirit:

First, the Holy life. Living holy means free from sin and positive thinking. Second, dare to preach the gospel. It means not being afraid in preaching the gospel, having a solid heart when facing challenges in preaching the gospel. Third, obedience to the Holy Spirit means to always submit, obey what is required. Full of wisdom. Wisdom means wisdom. Wisdom is different from intelligence. Wisdom comes from God. The attitudes reflected from the wise are: First, wise. Wise means being clever and careful in solving problems. 
Second, being humble, which means not being arrogant, can accept suggestions and criticisms.

Third, fair which means not taking sides. Fourth, moral, it means having good moral / living according to morals. These three qualifications for God's service became the standard for selecting deacons / servants of God in the early church / apostolic era. This qualification will also be a permanent and relevant reference for all time.

\section{REFERENCES}

[1]. Chris Marantika, Diktat Teologi Pertumbuhan Gereja(Yogyakarta: STTII,tt).

[2]. LAI, Alkitab.

[3]. Emanuel Gerrit Singgih,Iman dan Politik dalam Era Reformasi di Indonesia (Jakarta : BPK.Gunung Mulia, 2002).

[4]. Jan S.Aritonang \&Chr. De Jonge,Apa dan Bagaimana Gereja (Jakarta: BPK Gunung Mulia,2009).

[5]. Michael Griffiths, Gereja Dan

Panggilannya Dewasa Ini (Jakarta: BPK

Gunung Mulia,1995).

[6]. Chris Marantika, Diktat Teologi

Pertumbuhan Gereja (Yogyakarta: STTII,tt)

[7]. Jimmi Joses Sembiring,Smart HRD

Perusahaan Tenang Karyawan Senang

(Jakarta: Trasmedia Pustaka, 2010).

[8]. Marihot Tua Efendi Hariandja, Manajemen Sumber Daya Manusia (Jakarta: PT Grasindo,2007).

[9]. Paul G. Caram. Pedoman Bagi Hamba Tuhan (Jakarta : Voice of Hope,2007).

[10]. Sonny Eli Zaluchu. Pemimpin Pertumbuhan Gereja (Bandung : Yayasan Kalam Hidup, 2004).

[11]. George W.Peters. A Theology of Church Growth (USA: Zondervan Publishing House, 1982).

[12]. Suharto Harjowinoto dan Heru Susanto,Muda Berinvestasi, Tua Menikmati,
Mati Masuk Surga. Bertanggungjawab Terhadap Berkat Tuhan ( Jakarta : Elex Media Komputindo, 2004)

[13]. Asep Saepul Handi \&Bahrudin, Metode Penelitian Kuantitatif Aplikasi dalam Pendidikan, (Yogyakarta : DeePublish, 2012)

[14] Ballieth, Emil. Kisah Para Rasul. Malang: Gandum Mas,1982.

[15] Bambang, Yohanes Mulyono, Firman Hidup 55. Jakarta: BPK Gunung Mulia, 2002.

[16] Barclay, William. Pemahaman Alkitab Setiap Hari : Kisah Para rasul. Jakarta:Gunung Mulia, 2007.

[17] Bernstein, Stephen. Bernstein, Ruth. Elements Of Statistics. USA:The McGraw Hll Companies, 1999.

[18] Beutler, J. Exegetical Dictionary of the New Testament. William Publishing Company, 1990.

[19] Biblesoft's New Exhaustive Strong's Number and Concordance with Expanded Greek-Hebrew Dictionary. Bible Soft,Inc and International Publsher, 2006.

[20] Bible Knowledge Commentary/New Testamen. Cook Communications Ministries, 1983.

[21] Bible Exposition Commentary. Chariot Victor Publishing and Imprint of Cook Communication Ministries, 1989.

[22] Blankenbaker Frances, Inti Alkitab untuk Para Pemula, diterjemahkan Ny. D. Susilaradeya. Jakarta : BPK Gunung Mulia, 2007.

[23] Brink, H.V.D. Tafsiran Alkitab Kisah Para rasul. Jakarta: Gunung Mulia, 2000.

[24] Brink, Pamella J. \& Marilynn J. Wood. Langkah Dasar Dalam Perencanaan Riset Keperawatan. Jakarta: Buku Kedokteran EGC, 1995.

[25] Bungin, Burhan, Metodologi Penelitian Kuantitatif. Jakarta : Kencana, 2005. 
[26] Burns, Robert B., Introduction to Research Method, 4th Edition. French Forest NSW : Longman, 2000.

[27] Caram, G. Paul. Pedoman Bagi Hamba Tuhan. Jakarta : Voice of Hope, 2007

[28] Chapman, Adina. Pengantar Perjanjian Baru. Bandung: Yayasan Kalam Hidup,2007.

[29] Clarke's, Adam. Commentary Electronic, 2005.

[30] Conner, J. Cevin, Interpretting The Scriptures Hermeneutik. Malang : Gandum Mas, 2004.

[31] Colson, Charles. Arti Kehidupan Yang Kudus, Penerapan Praktis Pola Hidup Kristen Malang: Gandum Mas, 2002.

[32] Darwis, Sudarwan Danim, Metode Penelitian Kebidanan . Jakarta : EGC, 2002.

[33] Duyverman, M. E. Pembimbing ke dalam Perjanjian Baru. Jakarta: BPK. Gunung Mulia,2008.

[34] Dever, Mark. Tanda Gereja Yang Sehat. Surabaya: Momentum, 2010.

[35] Drane, John Memahami Perjanjian Baru:Pengantar Historis - Teologis, diterjemahkan P.G. Katoppo . Jakarta: BPK Gunung Mulia, 2005.

[36] Efendi, Hariandja \& Marihot Tua. Manajemen Sumber Daya Manusia. Jakarta: PTGrasindo, 2007.

[37] Eims, Leroi. 12 Ciri Kepemimpinan Efektif. Bandung: Kalam Hidup, 1994.

[38] Ellesse, Nindy. Hidup Bukan Teka-teki. Jakarta: Visimedia, 2007.

[39] Endra, Febri B.S., Pengantar metodologi Penelitian. Sidoarjo : Zifatama jawara, 2017.

[40] Endraswara Suwardi, Metode Penelitian Folklor. Yogyakarta : MedPress, 2009

[41] Fisher L. Don, Hermeneutik. Malang: Yayasan Gandum Mas, 2001.
[42] Free, D. Gordon, Hermeneutik Bagaimana Menafsirkan Firman Tuhan dengan Tepat. Malang : Gandum Mas, 2009.

[43] Gea, Antonius Atosokhi. Integritas Diri : Keunggulan Pribadi Tangguh. T.k.: t.p., t.t.

[44] Graham, Billy. Roh Kudus Kuasa Allah dalam Hidup Anda. Bandung: LBB, 2002.

[45] Grassmick, John D. Prinsip-Prinsip dan Praktek Eksegesis Bahasa Yunani. T.k.: t.p., t.t.

[46] Griffiths, Michael. Gereja Dan Panggilannya Dewasa Ini. Jakarta:Gunung Mulia,1995.

[47] Grant Robert M, Sejarah Singkat Penafsiran Alkitab. Jakarta: BPK. Gunung Mulia, 2000.

[48] Guthrie, Donald. Pengantar Perjanjian Baru Volume 1. Surabaya: Momentum, 2008.

[49] Hadi, Sutrisno , Metodologi Research, jilid 2. Yogyakarta: Gajah Mada University Press, 1977.

[50] Halley, Henry H. Penuntun Ke Dalam Perjanjian Baru. Surabaya: Yakin, 1979.

[51] Handi, Asep Saepul \& E. Bahruddin, Metode Penelitian Kuantitatif Aplikasi Dalam Pendidikan. Yogyakarta : Dee Publish, 2012.

[52] Harjowinoto, Suharto dan Heru Susanto. Muda Berinvestasi, Tua Menikmati, Mati Masuk Surga. Bertanggungjawab Terhadap Berkat Tuhan. Jakarta : Elex Media Komputindo, 2004.

[53] Hayes, John H\& Carl R. Hoslladay, Pedoman Penafsiran Alkitab. Jakarta: BPK. Gunung Mulia, 2002.

[54] Henry's, Mattew Commentary on the Whole Bible. Biblesoft inc, 2006.

[55] Hermawan, Asep \& Yusran Husna Leila, Penelitian Bisnis, Pendekatan Kualitatif. Jakarta : Kencana, 2017.

[56] Hubner, H. Exegetical Dictionary of the New Testament. William B.Eerdmans 
Publishing Holy Bible Contemporary Engllish Version. Jakarta: Lembaga Alkitab Indonesia, 1997.

[57] Ismail, Andar. Selamat Melayani Tuhan, 33 Renungan tentang pelayanan. Jakarta: BPK. Gunung Mulia, 2009.

[58] Iverson, Dick. Pelayanan Tim Memadukan Sebuah Tim yang Membuat Gereja Bertumbuh. Jakarta: Harvest Publication House, 1993.

[59] Jensen, L. Irving.Kisah Para Rasul. Bandung: Yayasan Kalam Hidup, 2000.

[60] Johar, S. Kamus Alkitab dan Theologi. Yogyakarta: ANDI, 2016.

[61] Joses, Jimmi Sembiring. Smart HRD Perusahaan Tenang Karyawan Senang. Jakarta: Trasmedia Pustaka, 2010.

[62] Kittel dan Bromiley, Theological Dictionary of the NewTestament (Abridged). BibleWorks V10.

[63] LAI. Alkitab Edisi Studi. Jakarta: Lembaga Alkitab Indonesia, 2010.

[64] Lea, Larry, Hikmat Janganlah Menghayati Hidup Tanpa HikmatJakarta: Yayasan Pekabaran Injil "Immanuel”, 1999.

[65] Lulu, Yosef. Makna Hidup Dalam Terang Iman Katolik. Yogyakarta: Kanisius, 2010.

[66] Layantara, Agnes Maria. Pedoman Lengkap Pemahaman Alkitab. Bandung: Yayasan kalam Hidup, 2002.

[67] Lea, Larry. Hikmat Janganlah Menghayati Hidup Tanpa Hikmat. Jakarta: Yayasan Pekabaran Injil "Immanuel”, 1999.

[68] Leigh,Ronald w. Melayani dengan Efektif, 34 Prinsip Pelayanan bagi Pendetaan Kaum Awam. Jakarta: Gunung Mulia, 2007.

[69] London Jr, H.B. Pelayan Allah yang Berjiwa Besar. Jakarta: Yayasan Pekabaran Injil "Imanuel”,1999.

[70] Lontoh, Frederich Oscar. "Pengaruh Gaya Kepemimpinan, Ketrampilan Komunikasi Dan
Kotbah Terhadap Komitmen Organisasional Jemaat Di GKI Dasa Surabaya." Journal Kerusso 2.1 (2017): 1-17.

[71] Marantika,Chris.Doktrin Keselamatan. Yogyakarta: Iman Press, 2002.

[72] Marantika, Chris. Diktat Teologi Pertumbuhan Gereja. Yogyakarta: STTII,

[73] Martono, Nanang, Metode Penelitian Kuantitatif . Jakarta : PT Raja Grafindo Persada, 2012

[74] Marxsen, Willi. Pengantar Perjanjian Baru Pendekatan Kritis Terhadap MasalahMasalahnya. Jakarta: Gunung Mulia,2008

[75] Metzger, Bruce M., A textual Commentary On The Greek New Testament. USA : Hendrickson, 2005

[76] Meyer, Joyce. Pemimpin Yang Sedang Dibentuk. Jakarta: Imanuel,2004.

[77] Mulyono, Yohanes Bambang. Firman Hidup 55. Jakarta: BPK Gunung Mulia,2002.

[78] Nasution, H.P. Tafsiran aalkitab Masa Kini 3 Matius-Wahyu. Jakarta:YKBK OMF,1982.

[79] Newman, B.M. \& E.A. Nida, A Handbook On The Acts Of The Apostless (UBS Hanbook Series New Testament Volumes). PC Bible Study V5.

[80] Noordegraaf. Orientasi Diakonia Gereja Teologi dalam Perspektif Reformasi Jakarta:Gunung Mulia,2004.

[81] NoorJuliansyah, Metode Penelitian, Skripsi, Tesis, Desertasi dan Karya Ilmiah Jakarta; Kencana, 2017.

[82] Oktavia Boby Firman, Pengaruh Sikap Kejujuran dan Disiplin Siswa Terhadap Prestasi Belajar Matematika Materi sifat-sifat bangun datar di kelas V SD Negeri 1 Tinggarjaya. Purwokerto : Universitas Muhammadiyah, 2014.

[83] Osbone Grant R. Spiral Hermeneutika, Pengantar Konfrehensif Bagi penafsiran Alkitab. Surabaya : Momentum, 2012. 
[84] Permana, Surja, et al. "Memorizing Bible Verses with the Association Method of Quantum Learning in Sunday School." Journal Didaskalia 2.1 (2019): 1-5.

[85] Peters W, George. A Theology of Church Growth. Amerika Serikat: Zondervan Publishing House, 1982.

[86] Pfeiffer, Charles Fdan Everett F Harrison,. Tafsiran Alkitab Wycliffe volume 3 Perjanjian Baru. Malang: Gandum Mas,2001.

[87] Pratama, Joseph, Felix. Agama dan Kepercayaan Membawa Pembaharuan. Yogyakarta : Kanisius, 2006

[88] Prayitno, Dwi, Mandiri Belajar SPSS. Jakarta : Media Kencana, 2010.

[89] Priyatno Dwi, Paham Analisis Statistika Data dengan SPSS. Yogyakarta: Media Kom, 2010

[90] Rondah, Daniel, Jurnal Jaffray is Nation Accredited by Kemristekdikti, No SK : 21/E/KPT/2018 Volume 14 No. 1 April 2016 until Volume 2 Oktober 2020

[91] Rumiyati, Rumiyati, et al. "Pengaruh Kepemimpinan Hamba Tuhan Dalam Pertumbuhan Kerohanian Jemaat Gereja GPdI 'Zion'Krebet, Tembalang, Wlingi-Blitar." Journal Kerusso 3.2 (2018): 9-19.

[92] Sanders, J. Oswalld. Kedewasaan Rohani. Bandung : Kalam Hidup,1962

[93] Santoso, Singgih. Mengatasi Berbagai Masalah Statistik dengan SPSS Versi 11.5 Jakarta: PT Elex Media Komputindo,2003.

[94] Sembiring, M.K. Pedoman Penafsiran Alkitab Kisah Para Rasul. Jakarta : LAI dan Yayasan Kartidaya, 1988.

[95] Sembiring, MK. Pedoman Penafsiran Alkitab Injil Lukas. Jakarta: LAI dan Yayasan Kartidaya, 2005.

[96] Zaluchu, Sonny Eli. Pemimpin Pertumbuhan Gereja. Bandung: Yayasan Kalam Hidup, 2004. 